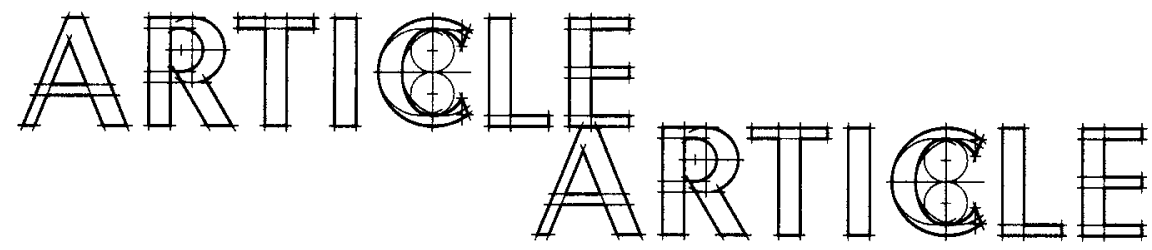

\title{
Competency Corner, Part One: Optometrists - What do we do?
}

\section{Coin des compétences: Optométristes - Quelles sont nos tâches?}

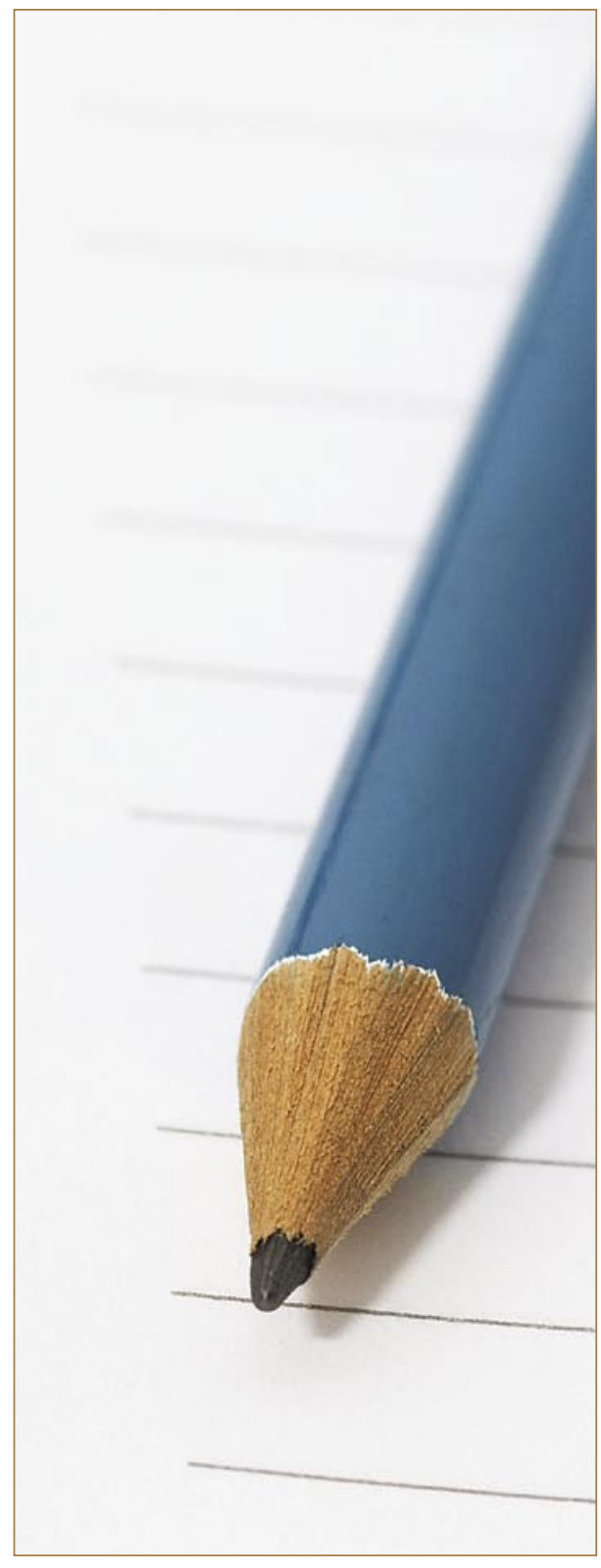

\section{Abstract}

In 2001 the Canadian Examiners of Optometry mandated the Competence Committee to describe the competencies required of Canadian Optometrists to provide safe and effective optometric care. The goal of this work was to provide a framework for revision of the Canadian Standard Assessment in Optometry so that questions on this exam could be directly linked to the practise-requirements of Canadian Optometrists. Work from the World Health Organization (WHO) provided an excellent foundation for the Competence Committee's deliberations, emphasizing that Optometrists have professional responsibilities beyond providing eye and vision care. The Competence Committee followed WHO's framework and identified four critical roles of Optometrists. These roles relate to: $i$. providing eye and vision care; $i$. collaborating with and referring to other bealth care providers; iii. managing their practice, and; iv. educating within their profession. A second set of general attributes was also identified. These general attributes are needed to successfully perform the majority of the professional competencies. The Competence Committee identified five underlying general attributes: knowledge, reasoning and skills; planning and implementation; communication; values and ethics; and, selfdirected learning. The next article in this four part series provides the detailed descriptions of these professional competencies and underlying general attributes required of Canadian Optometrists.

Résumé:

En 2001, les Examinateurs canadiens en optométrie ont demandé au Comité des compétences de décrire les
For the Competence Committee of the

Canadian Examiners in

Optometry. (2001-2002)

T. Winslade (Co-Chair,

Competence Committee),

N. Winslade (External

Consultant, Competence

Committee), R. Chou

(Co-Chair, Competence

Committee), S. Burbine

B. Hawkins, L. Ryall

December 2006

This article of Competency Corner is Part One of a

Four Part series.

\section{A N A D I A N J O U R N A L \\ R E V U E C A N A D I E N N E

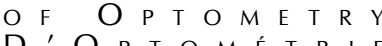 \\ $D^{\prime}$ O $P$ T $O$ O M É T R I E}


compétences nécessaires aux optométristes canadiens pour offrir des soins optométriques sécuritaires et efficaces. Le but de ce travail était de fournir un cadre pour la révision de l'Évaluation canadienne standardisée en optométrie afin que les questions de cet examen soient directement liees aux exigences de pratique des optométristes canadiens. Le travail de l'Organisation mondiale de la Santé (OMS) a fourni une excellente base aux discussions du Comité des compétences, soulignant que les optométristes ont des responsabilités professionnelles qui vont au-delà des soins de la vue et des yeux. Le Comité des compétences a suivi le cadre de l'OMS et déterminé quatre rôles de première importance pour l'optométriste : i. fournir des soins de la vue et des yeux; ii. collaborer avec d'autres fournisseurs de soins de santé et les consulter; iii. gérer sa pratique, et; iv. se former. Il a aussi établi un second ensemble d'attributs généraux, nécessaires pour bien accomplir la majorité des tâches professionnelles. Le Comité des compétences a dégagé cinq attributs généraux sous-jacents : connaissance, raisonnement et compétences; planification et mise en cuvre; communication; valeurs et éthique; et, autoformation. Le prochain article de cette série de quatre présentera une description détaillée de ces compétences professionnelles et attributs généraux sous-jacents nécessaires aux optométristes canadiens.

W hat would you do if someone asked for a description of every important action done in the role as a practicing Optometrist in Canada? Imagine that you were told the professional future of those entering practice depended on this fair description. The explanation would have to be complete and also rate how important each action was to the safety of your patients. And what if you were asked to make sure the list was organized in a manner that would be understood around the world?

Don't panic, this is not a homework assignment but a glimpse at the task faced by members of the Competence Committee of the Canadian Examiners in Optometry in 2001. Since 1995, the Canadian Examiners in Optometry (CEO) has administered the Canadian Standard Assessment in Optometry (CSAO). The CSAO measures competence - the ability of candidates to provide safe and effective optometric care in Canada. In the fledgling years of establishing the CSAO, CEO used the American National Board of Examiners in Optometry (NBEO) model and based the exam on a syllabus, much like a university course. This syllabus described the range of topics assessed in a complete and detailed manner. The link between each detailed item of knowledge, skill or judgment and the daily activities required of practising Optometrists was, however, less clear. Demonstration of such a link strengthens the validity of the examination process and makes it consistent with professional qualifying examinations of other health professions ${ }^{1}$. Unlike the National Board Exams, which are written as the student proceeds through their optometric education, the CSAO is taken after graduation. As these differences became more apparent, CEO realized that a Canadian description of competence was required. The CEO Competence Committee was created to complete this task. This article, and the following three in the series, describes the work of the Competence Committee to support the transition of the CSAO to a competencebased exam.

Where to start? It was a daunting task. The committee members began by researching the literature to determine if any professions had addressed this same task. The members started with the World Health Organization (WHO) as the WHO personnel had been interested in this topic for several years. In the mid 1980's WHO completed a worldwide survey of training programs for physicians and nurses ${ }^{2}$. In analyzing their results they noticed a striking similarity among the functions listed by programs around the world and summarized these responsibilities as:

The professional responsibilities of identifying and analyzing health problems to:

Provide treatment

Provide preventative care

Plan policies, activities and services (management)

Participate in the health education of the population

Collaborate with other services

Train health personnel

Participate in research 


\section{ARTICLE ARTICLE}

The self-oriented responsibilities of using methodologies to:

Evaluate one's own activities

Develop one's own skills continuously

WHO went on to state that it was not surprising that all health professionals should have similar responsibilities at a very broad level and that the differences among the health professions would emerge from the more detailed descriptions of tasks associated with these responsibilities.

This work from WHO provided an excellent foundation for the Competence Committee's deliberations, emphasizing that Optometrists have professional responsibilities beyond providing eye and vision care. In its first year of deliberations, the Competence Committee followed WHO's framework and identified four critical roles of Optometrists. These roles relate to: $i$. providing eye and vision care; ii. collaborating with and referring to other health care providers; iii. managing their practice, and; iv. educating within their profession. The Competence Committee created brief descriptions of these roles, again using literature as a baseline. For the descriptions, the Committee adapted work from the Association of Faculties of Pharmacy of Canada ${ }^{3}$ and the National Association of Pharmacy Regulatory Authorities ${ }^{4}$, resulting in the following descriptions:

\section{Competence Committee's Key Roles}

for Competence as a Canadian Optometrist

Provide comprehensive eye and vision care: Optometrists meet patients' eye and vision care-related needs with the objectives of achieving appropriate outcomes and maintaining or improving patients' quality of life.

Collaborate: Optometrists support an integrated health care system by collaborating with other health care professionals and service providers to facilitate the management of the overall health needs, and to encourage the well-being, of patients.

Manage: Optometrists apply management skills to optimize the care of patients and make efficient use of health resources.

Educate: Optometrists provide education with the goal of encouraging appropriate, effective and comprehensive eye and vision care.
The next challenges faced by the Committee were twofold:

(1) To describe these various roles in a thorough, structured, succinct and understandable manner.

2 To incorporate WHO's self-oriented responsibilities such as self assessment and continuous professional development.

A series of research reports written by the Australian Office of Education, Employment and Training addressed these two issues ${ }^{5}$. This group had focused on developing both specific methodologies for describing the performance expected of professionals and specific terminology to use so that such descriptions could be compared among different professions and across professions within different countries. This group also recommended that, in defining competencies for a profession, focus be maintained on the professional competencies such as providing primary care and collaboration. A second set of general attributes should also be identified that underlay the successful performance of these professional competences. Since several of these general attributes would be required to perform each professional competency the professional competencies and general attributes would be cross-linked. The underlying attributes discussed included WHO's concepts of self-assessment and continuing professional development along with others such as communication and professionalism. The Competence Committee modified, with permission, work from the Association of Faculties of Pharmacy of Canada to identify the following general attributes that underlay Optometrist's successful performance of the professional competencies required of Optometrists.

\section{General Attributes Necessary to Fulfill the Professional Competencies \\ (1) Knowledge, reasoning and skills.}

Optometrists have knowledge and comprehension of the core information associated with their profession. They are able to make evidence-based decisions during daily practice and to apply their knowledge to appropriately perform required professional skills.

(2) Planning and implementation.

Optometrists have effective planning and implemen-
C A N A D I A N J O U R N A L O F O P T O METR Y

R E V U E C A N A D I E N N E D'O P T O M É T R I E
Vol 69 No 2

March / mars 2007 
tation abilities including time management, resource management, delegation skills and organizational skills. Optometrists have the necessary skills to plan and implement change, to understand and consider the human reaction to change, and to recognize when change is required for fulfillment of professional and societal responsibilities.

\section{(3) Communication.}

Optometrists have effective communication skills, including the ability to effectively use and respond to written, verbal and non-verbal communications.

\section{(4) Values and ethics.}

Optometrists are able to apply ethical principles in professional and social contexts. They will have developed a behaviour that both recognizes and respects cultural and personal variability in values, communication and life styles. Optometrists will apply ethical principles when decision-making and will take responsibility for outcomes associated with their decisions.

\section{(5) Self-directed learning.}

Optometrists have self-directed learning capabilities in order to maintain and advance their practice and professional role in society. They will be able to effectively self assess and use feedback from others to identify their learning needs and to satisfy these needs on an ongoing basis.

In the next article we will explain the template used by the Competence Committee to describe the professional competencies in detail, and the vocabulary used to describe competence as an Optometrist in Canada.

\section{REFERENCES}

1 Pharmacy Examining Board of Canada. Qualifying Examination Blueprint. www.pebc.ca. 2003.

2 Guilbert, J.J. Educational Handbook for Health Personnel Sixth Edition. World Health Organization, Geneva. 1987.

3 Association of Faculties of Pharmacy of Canada Outcomes for a Baccalaureate in Pharmacy Graduate in Canada. 1997

4 National Association of Pharmacy Regulatory Authorities. Model Standards of Practice for Canadian Pharmacists - first revision. Ottawa, Ontario. www.napra.org. 2002.

5 Gonczi, A., Hager, P., Oliver, L. Research paper No. 1: Establishing Competency-based standards in the professions. Australian Government Publishing Service, Canberra. 1990.

\section{CAO CONGRESS 2007}

\section{SASKATOON \\ SHINES \\ JuLY 18 - 22}

Join us to

experience

one of the best

Congresses ever!

An incredible

schedule of events

is planned for you

and your family.

With numerous pre

$\&$ post Congress

holiday options,

we encourage you

to arrive early and

extend your stay in

sunny Saskatchewan.

Registration Forms

\& more information

about Congress can

be found on the

CAO website,

WWW.OPTO.CA
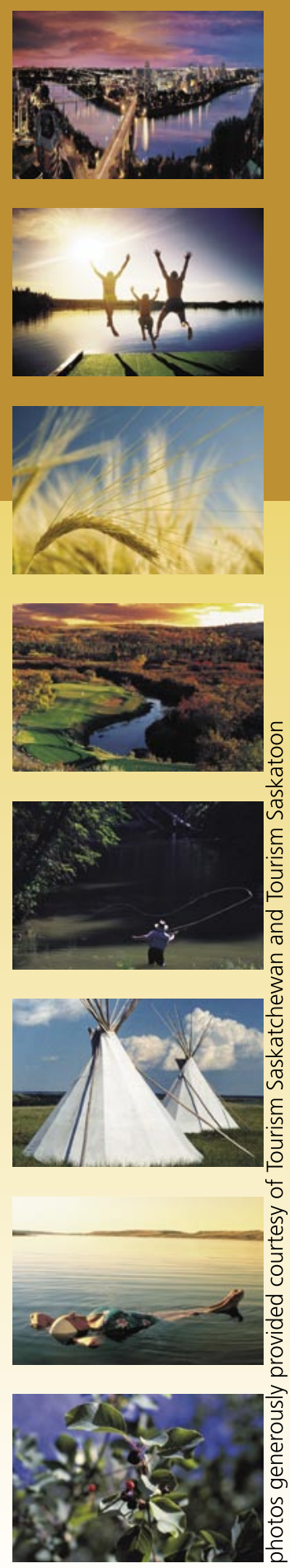